\title{
Renata Badowiec
}

\section{Związanie sądów karnych \\ prawomocnymi orzeczeniami sądów cywilnych}

\section{na przykładzie spraw o przestępstwa uchylania się od alimentacji}

\begin{abstract}
Streszczenie
Pomimo obowiązywania $\mathrm{W}$ polskim postępowaniu karnym zasady samodzielności jurysdykcyjnej sądu, zgodnie z którą sąd karny rozstrzyga samodzielnie zagadnienia faktyczne i prawne, a także nie jest związany rozstrzygnięciem innego sądu lub organu, ustawodawca przewidział od niej odstępstwa. Sąd w postępowaniu karnym związany jest bowiem prawomocnymi rozstrzygnięciami sądu kształtującymi prawo lub stosunek prawny. Pomimo różnic istniejących między postępowaniami karnymi oraz postępowaniami cywilnymi, obojętnym nie powinien pozostawać fakt wpływu orzeczeń wydanych w toku postępowania cywilnego na toczące się postępowanie karne. Takie rozstrzygnięcie będzie bowiem oddziaływało na kształt owego postępowania oraz na decyzje podejmowane przez sąd karny. Przykładem są orzeczenia sądów cywilnych wywierające wpływ na wyroki sądów karnych wydawane w przedmiocie przestępstwa uchylania się od alimentacji. Na ich przykładzie wykazane zostanie, w jakim zakresie sąd ograniczony jest w swojej samodzielności podczas orzekania w postępowaniu karnym.
\end{abstract}

\section{Wstęp}

Jeszcze pod rządami poprzednio obowiązującego kodeksu postępowania karnego z 1969 r. ${ }^{1}$ pojawiały się prace dotyczące zasady samodzielności jurysdykcyjnej sądu karnego i jej granic oraz związania orzeczeniami sądów cywilnych mimo braku regulacji, która bezpośrednio odnosiłaby się do tej zasady. W kodeksie z 1969 r. ograniczenie samodzielności jurysdykcyjnej ujęte zostało bowiem w jednym przepisie z zasadą swobodnej oceny dowodów. W obecnie obowiązującym kodeksie postępowania karnego z 1997 r. uregulowana została zasada samodzielności jurysdykcyjnej, zgodnie z którą sądy karne samodzielnie rozstrzygają

\footnotetext{
${ }^{1}$ Ustawa z 19.4.1969 r. Kodeks postępowania karnego, Dz.U. z 1969 r., Nr 13, poz. 96 z późn. zm.
} 
zagadnienia faktyczne i prawne, a ponadto nie są związane rozstrzygnięciem innego sądu lub organu. Pomimo jednak istnienia tej zasady w polskim porządku prawnym, istnieją od niej odstępstwa, bowiem sąd karny związany jest prawomocnymi rozstrzygnięciami sądu kształtującymi prawo lub stosunek prawny. Pomimo obecnych różnic między postępowaniem karnym i postępowaniem cywilnym, obojętnym nie powinien pozostawać fakt wpływu orzeczeń wydanych w toku postępowania cywilnego na toczące się postępowanie karne. Takie rozstrzygnięcie będzie bowiem oddziaływało na kształt owego postępowania oraz na decyzje podejmowane przez sąd karny.

Niniejsze opracowanie ma służyć analizie zagadnienia związania sądu karnego orzeczeniami sądu cywilnego w sprawach o przestępstwo uchylania się od alimentacji. Temat ten został podjęty ze względu na chęć wykazania istotnych zależności między postępowaniem karnym i postępowaniem cywilnym z uwagi na istniejące odstępstwa od zasady samodzielności jurysdykcyjnej sądu karnego. Co do zasady postępowania te różnią się między sobą przedmiotem oraz celem (postępowanie cywilne ma służyć rozpoznawaniu spraw cywilnych, czy też przymusowemu wykonywaniu orzeczeń sądowych, natomiast celem postępowania karnego jest takie jego ukształtowanie, aby sprawca przestępstwa został wykryty i pociągnięty do odpowiedzialności karnej, a osoba niewinna takiej odpowiedzialności nie poniosła). Ponadto postępowanie karne, w przeciwieństwie do postępowania cywilnego, kształtuje i reguluje stosunki społeczne w sposób pośredni, samo postępowanie także wyróżnia się pewnego rodzaju specyfiką ze względu na atrybuty przysługujące sądowi w toku postępowania karnego.

\section{Wpływ zakończonego prawomocnym orzeczeniem postępowania cywilnego na postępowanie karne}

Źródeł wzajemnych powiązań ustaleń faktycznych należy szukać w materialnej istocie norm prawa karnego i norm pozostałych dziedzin prawa. Decydujące jest to, w jakiej mierze dany odcinek rzeczywistości może być przedmiotem zainteresowania prawa karnego i jednocześnie innej gałęzi prawa, np. prawa cywilnego ${ }^{2}$. W praktyce zdarzają się sytuacje, kiedy postępowanie cywilne zostało zakończone prawomocnym orzeczeniem, natomiast postępowanie karne jeszcze się toczy, a rozstrzygnięcie, które zapadło w zakończonym już postępowaniu cywilnym jest wiążące dla tego drugiego. $Z$ tego punktu widzenia istotne są dwie regulacje: jedna, zawarta w kodeksie postępowania cywilnego, dotycząca zakresu związania

\footnotetext{
${ }^{2} \mathrm{~K}$. Chwalibogowski, Ustalenia faktyczne w procesie karnym i cywilnym i ich wzajemna moc wiążaca, NP 1956, nr 9, s. 50.
} 
prawomocnym orzeczeniem sądu cywilnego i druga, znajdująca się w kodeksie postępowania karnego i odzwierciedlająca zasadę samodzielności jurysdykcyjnej sądu w postępowaniu karnym.

Pierwsza z wyżej wskazanych regulacji dotycząca mocy wiążącej prawomocnego orzeczenia wydanego w postępowaniu cywilnym, wyrażona została w art. 365 k.p.c. ${ }^{3}$ i stanowi o związaniu innych sądów i organów rozstrzygnięciem sądu cywilnego ${ }^{4}$. Wskazać należy, iż podstawę do uznania mocy wiążącej danego orzeczenia stanowi prawomocność orzeczenia w rozumieniu art. $363 \S 1$ k.p.c. (,orzeczenie sądu staje się prawomocne, jeżeli nie przysługuje co do niego środek odwoławczy lub inny środek zaskarżenia") ${ }^{5}$. Instytucja uregulowana w art. 365 k.p.c. nazywana jest prawomocnością materialną albo aspektem materialnym prawomocności bądź też pozytywnym aspektem prawomocności materialnej. Regulacja ta znajduje zastosowanie do wszelkich orzeczeń sądów i innych organów, które zostały wydane $\mathrm{w}$ procesie cywilnym oraz innych postępowaniach uregulowanych w k.p.c. Istotny jest fakt, iż art. 365 k.p.c. dotyczy wyłącznie orzeczeń istniejących. Rozstrzygnięciem nieistniejącym jest takie, które nigdy nie zaistniało w sensie prawnym albo zostało prawomocnie uchylone ${ }^{6}$. Jeżeli chodzi o kwestie wiążących elementów orzeczenia wydanego w postępowaniu cywilnym, to w orzecznictwie utrwalona została zasada, iż wynikająca z art. 365 k.p.c. moc wiążąca dotyczy związania sentencją, a nie uzasadnieniem wyroku innego sądu, czyli przesłankami faktycznymi i prawnymi, które zostały przyjęte za jego podstawę, ponieważ zakresem prawomocności materialnej objęty jest wyłącznie ostateczny wynik rozstrzygnięcia (a nie jego przesłanki) ${ }^{7}$.

Artykuł $365 \S 2$ k.p.c. stanowi, że w przypadku związania prawomocnymi orzeczeniami sądów cywilnych, to kodeks postępowania karnego wyznacza zakres tego związania. W związku z tym, gdy chodzi o postępowanie prowadzone przez sąd karny, jako punkt wyjścia należy przyjąć zasadę samodzielności jurysdykcyjnej sądu. Została ona uregulowana w art. $8 \S 1$ k.p.k. ${ }^{8}$, który stanowi, iż sąd karny rozstrzyga zagadnienia faktyczne oraz prawne

\footnotetext{
${ }^{3}$ Ustawa z 17.11.1964 r. - Kodeks postępowania cywilnego, t.j.: Dz.U. z 2020 r., poz. 1575 ze zm., dalej jako ,k.p.c.”.

${ }^{4}$ K. Piasecki, Wyroki sądów pierwszej instancji, sądów apelacyjnych oraz Sądu Najwyższego w sprawach cywilnych, handlowych i gospodarczych, Warszawa 2007, s. 135.

${ }^{5}$ Ibidem, s. 134.

${ }^{6}$ I. Kunicki, [w:] Kodeks postepowania cywilnego. Tom I. Komentarz. Art. 1-366, red. A. Marciniak, K. Piasecki, Warszawa 2017, s. 1124.

${ }^{7}$ Wyrok SN z 15.1.2015 r., sygn. akt. IV CSK 181/14, Legalis nr 1180601; podobnie wyrok SN z 13.1.2011 r., sygn. akt. III CSK 94/10, Legalis nr 417545; wyrok SN z 4.3.2009 r., sygn. akt. IV CSK 441/08, Legalis nr 244088; wyrok SN z 3.6.2008 r., sygn. akt. I PK 301/07, Legalis nr 174646; wyrok SN z 13.3.2008 r., sygn. akt. III CSK 284/07, Legalis nr 114967 i inne.

${ }^{8}$ Ustawa z 6.6.1997 r. - Kodeks postępowania karnego, t.j.: Dz.U. z 2021 r., poz. 534 ze zm., dalej jako „,k.p.k.”.
} 
samodzielnie, a także nie jest on związany rozstrzygnięciami innych sądów lub organów. W związku z tym należy przyjąć, że wszelkie ustalenia faktyczne, które zostały poczynione przez sąd w postępowaniu cywilnym, nie mogą być podciągnięte do rangi jakichkolwiek środków dowodowych wykorzystywanych w postępowaniu karnym. Rozstrzygnięcia sądów cywilnych wraz z zawartymi w uzasadnieniu ustaleniami faktycznymi mogą być oczywiście odczytywane na rozprawie karnej i mogą być traktowane jako dokumenty. Takie orzeczenie będzie jednak dokumentem dowodzącym jedynie, iż zapadło rozstrzygnięcie o określonej formie i treści ${ }^{9}$. W tym względzie chodzi więc o takie orzeczenia wydane w postępowaniu cywilnym, które stwierdziły wyłącznie istnienie jakiegoś stanu, czyli miały charakter deklaratoryjny. Wówczas sąd w postępowaniu karnym ma możliwość zbadania, czy stan stwierdzony w tym rozstrzygnięciu rzeczywiście istnieje. Sąd karny może bowiem mieć wątpliwości, czy orzeczenie wydane w postępowaniu cywilnym jest zgodne z prawdą. Dlatego też sąd karny ma możliwość samodzielnie poszukiwać prawdy ${ }^{10}$.

Inaczej jednak kształtuje się kwestia dotycząca prawomocnych orzeczeń sądu cywilnego kształtujących prawo lub stosunek prawny. W tym bowiem względzie, zgodnie z art. $8 \S 2$ k.p.k., sąd w postępowaniu karnym związany jest takimi rozstrzygnięciami. Takie rozwiązanie stanowi wyjątek od zasady samodzielności jurysdykcyjnej sądu karnego. W przypadku więc, gdy sąd w postępowaniu cywilnym, opierając się na obowiązujących przepisach prawa, stworzył nowy stan prawny w zakresie stosunków prawnych określonych podmiotów prawa, a ten stan nie może być później w myśl tych przepisów zmieniany w inny sposób niż w drodze kolejnego prawomocnego wyroku cywilnego, to sąd w postępowaniu karnym musi uznać owy stan. W tej bowiem sytuacji dla sądu karnego ustalony wcześniej stan prawny jawi się jako konkretna rzeczywistość. Jako przykład wskazać można wyrok sądu cywilnego rozwiązujący małżeństwo przez rozwód i związanie nim sądu w postępowaniu karnym $^{11}$. Istotne jest również, że zainteresowaniu orzekającego w postępowaniu karnym sądu powinien podlegać już sam fakt wydania orzeczenia przez sąd cywilny, a także jego treść, a zwłaszcza to, czy w podstawach ustaleń faktycznych orzeczenia zapadłego w innej sprawie nie znalazły się dowody istotne również $\mathrm{z}$ punktu widzenia rozpoznawanej sprawy, dotąd w niej nieprzeprowadzone ${ }^{12}$.

\footnotetext{
${ }^{9}$ K. Chwalibogowski, op.cit., s. 56.

${ }^{10} \mathrm{~W}$. Siedlecki, Stosunek postępowania karnego do postępowania cywilnego w świetle przepisów nowego kodeksu postępowania cywilnego, „Palestra” 1966, nr 9, s. 32.

${ }^{11}$ Ibidem.

${ }^{12}$ Wyrok SN z 3.12.2007 r., sygn. akt. V KK 96/07, Legalis nr 164535.
} 
W nauce nie było zgodności co do charakteru art. $8 \S 2$ k.p.k. Już na gruncie poprzednio obowiązującego kodeksu postępowania karnego, w którym kwestie samodzielności jurysdykcyjnej i związania sądu karnego prawomocnymi orzeczeniami sądów cywilnych uregulowane były w innym przepisie, wyrażane były odmiennie zdania w tym względzie. Z. Świda-Łagiewska opowiedziała się za poglądem, że regulacja ta stanowi ograniczenie zasady swobodnej oceny dowodów, co potwierdzało umieszczenie tego wyjątku w jednym artykule wraz z przepisem konstytuującym wyżej wskazaną zasadę. Zgodnie jednak z odmiennym stanowiskiem należało wziąć pod rozwagę, czy wyjątek od zasady samodzielności jurysdykcyjnej sądu karnego stanowi ograniczenie swobody w ocenie dowodów, czy jednak ogranicza zakres samego przedmiotu dowodzenia. Odmienne stanowisko w tej kwestii zajął R. Kmiecik. Wskazał, że przepis art. $8 \S 2$ k.p.k. dotyczy tzw. prejudycjalności, czyli materii związanej z samym procesem odtwarzania faktów, zwłaszcza z oceną dowodów. Istniejące więc prawomocne orzeczenie sądu cywilnego wiąże sąd karny w zakresie stanu prawnego, który został ukształtowany, natomiast nie zostaje ograniczona swoboda sądu w dokonywaniu ustaleń faktycznych stanowiących podstawę prawomocnego orzeczenia wydanego w postępowaniu cywilnym. Według drugiego stanowiska art. $8 \S 2$ k.p.k. określa ograniczenia dotyczące oceny prawnej faktów, a nie sfery ich ustalania ${ }^{13}$.

Rozważenia wymaga termin „rozstrzygnięcie”, jakim posługuje się art. $8 \S 2$ k.p.k.. W kodeksie postępowania karnego ustawodawca używa go wielokrotnie, jednak często nadaje mu inne znaczenie. Nie w każdym przypadku traktuje je jako „orzeczenie”. W pewnych przypadkach chodzi bowiem o czynność, jaką jest „orzekanie” (np. art. 2 § 1 pkt 4 k.p.k. - „ma na celu (...), aby rozstrzygnięcie sprawy nastąpiło w rozsądnym terminie”), a niekiedy mowa jest o rozstrzygnięciu jako elemencie orzeczenia (np. art. $413 \S 1$ pkt 5 k.p.k. - „każdy wyrok powinien zawierać rozstrzygnięcie sądu”). W art. 8 § 2 k.p.k. pojęcie „rozstrzygnięcie” zostało użyte w formie rzeczownikowej, dlatego też można przyjąć, iż w tym przypadku chodzi o pojmowanie tego terminu jako decyzji procesowej ${ }^{14}$.

Z powyższych rozważań wynika, iż w kwestii związania sądu w postępowaniu karnym, ogranicza się ona wyłącznie do związania prawomocnym rozstrzygnięciem (czyli decyzji procesowej - wyroku lub innego orzeczenia wydanego przez sąd cywilny), które ma charakter konstytutywny, tj. kształtuje prawo lub stosunek prawny.

\footnotetext{
${ }^{13}$ P. Hofmański, Samodzielność jurysdykcyjna sądu karnego, Katowice 1988, s. 98-99.

${ }^{14}$ Ibidem, s. 99-100.
} 
MŁODY JURYSTA 2020/3

\section{Rodzaje orzeczeń sądów cywilnych}

Podział wyroków na konstytutywne i deklaratoryjne wynika ze swoistości stosunku między treścią normy prawnej a treścią rozstrzygnięcia. Zgodnie $\mathrm{z}$ klasycznym sformułowaniem M. Waligórskiego, w orzeczeniu deklaratoryjnym sąd uzupełnia jedynie stan prawny przez jego skonkretyzowanie, natomiast orzeczenie konstytutywne tworzy w sposób samodzielny nowy stan prawny lub zmienia też wcześniej obowiązujący stan prawny ${ }^{15}$.

Pojęcie orzeczenia konstytutywnego nie jest zdefiniowane w przepisach prawnych. Najczęściej jednak orzeczenia określane jako konstytutywne, noszą nazwę również prawotwórczych albo kształtujących. Słowo „konstytutywny” pochodzi z łacińskiego „constituere”, co oznacza tworzyć, wiązać, urządzać, organizować. Istotą orzeczenia konstytutywnego jako aktu stosowania prawa jest stworzenie nowego stanu prawnego, który będzie odpowiadał treści normy prawnej zrealizowanej i skonkretyzowanej $\mathrm{w}$ tym orzeczeniu $^{16}$. Jeżeli więc norma prawna będzie pozostawała decyzji sądu oznaczenie praw oraz obowiązków danego stosunku prawnego, a zdarzenia powstałe poza postępowaniem cywilnym same nie będą wywoływać skutków prawnych, ale uzasadniać będą wydanie orzeczenia, które dopiero określi owe prawa lub obowiązki (albo zmieni je lub uchyli), to takie właśnie orzeczenie będzie tworzyło nowy stan prawny, odpowiadający treści normy prawnej urzeczywistnionej za pomocą tego właśnie orzeczenia ${ }^{17}$.

Przy omawianiu zagadnienia tych orzeczeń należy wskazać, z jaką chwilą należy przyjąć oddziaływanie owego orzeczenia sądowego. Ta kwestia związana jest z prawomocnością wyroków cywilnych. Zasadą ogólną jest wystąpienie skutków związanych $\mathrm{z}$ orzeczeniem sądu w postępowaniu cywilnym z chwilą jego uprawomocnienia się, jeżeli przepisy szczególne nie stanowią inaczej. Natomiast sytuacja w przypadku nadania wyrokowi rygoru natychmiastowej wykonalności kształtuje się w inny sposób. Rygor natychmiastowej wykonalności może być nadany tylko wyrokowi, który nadaje się do wykonania w drodze egzekucji. Zasadniczo natomiast wyroki konstytutywne nie mogą być wykonywane w drodze egzekucji, ponieważ nie zasądzają one spełnienia określonego świadczenia. Wyjątkowo wyrok konstytutywny może mieć jednocześnie charakter zasądzający; w takiej sytuacji, gdy zostanie

\footnotetext{
${ }^{15}$ K. Piasecki, Wyrok pierwszej instancji w procesie cywilnym, Warszawa 1981, s. 139.

${ }^{16}$ K. Korzan, Orzeczenia konstytutywne w postepowaniu cywilnym, Warszawa 1972, s. 79-80.

${ }^{17}$ Z. Kwiatkowski, Zakazy dowodowe w procesie karnym, Katowice 2001, s. 109.
} 
mu nadany rygor natychmiastowej wykonalności, z chwilą wydania owego wyroku powstanie stan prawny uzasadniający spełnienie zasądzonego świadczenia ${ }^{18}$.

Omawiając problematykę orzeczeń konstytutywnych sądów cywilnych nie sposób nie odnieść się do skutków owych orzeczeń. Na wstępie należy wskazać, że w szerokim ujęciu można mówić o wykonalności i skuteczności jako następstwie danego orzeczenia, bowiem bez jego wydania takie skutki nie mogłyby wystąpić. Kolejnym aspektem, na który trzeba zwrócić uwagę omawiając kwestię skutków orzeczeń konstytutywnych, jest podział owych skutków na wewnętrzne i zewnętrzne. Skutki wewnętrzne prowadzą do definitywnego zamknięcia toku postępowania. Orzeczenie takie jest skutkiem procesowej działalności sądu ${ }^{19}$. Do skutków zewnętrznych należy natomiast prawomocność materialna danego orzeczenia wydanego przez sąd w toku postępowania cywilnego. Prawomocność została uregulowana w art. 365 k.p.c. Przepis ten stanowi, że orzeczenie prawomocne wiąże nie tylko strony i sąd, który wydał to orzeczenie, ale także inne sądy oraz inne organy państwowe i organy administracji publicznej, a w wypadkach, które zostały przewidziane w ustawie - także inne osoby. Ze związaniem innych osób orzeczeniem wydanym przez sąd w postępowaniu cywilnym będziemy mieli więc do czynienia, gdy wystąpi tzw. rozszerzona prawomocność materialna orzeczenia, a w zasadzie taka sytuacja wystąpi, kiedy zaistnieją wypadki wskazane w ustawie. Jeśli chodzi natomiast o związanie innego sądu owym orzeczeniem, to należy rozumieć je jako niemożność dokonania przez sąd odmiennej oceny prawnej roszczenia, gdy w tej innej sprawie występują te same strony albo też osoby objęte rozszerzoną prawomocnością. Ponadto między prawomocnym orzeczeniem sądu cywilnego a toczącą się sprawą zachodzi szczególnie istotny związek polegający na tym, że prawomocne orzeczenie oddziałuje na rozstrzygnięcie $\mathrm{w}$ toczącej się właśnie sprawie ${ }^{20}$.

Powołując się na wyżej wskazany podział powództw, należy wskazać, że orzeczenia konstytutywne wydawane są przez sąd cywilny w przypadku powództw o ukształtowanie prawa lub stosunku prawnego. Rozważania dotyczące tego powództwa rozpocząć należy od wskazania, iż ich źródłem mogą być normy prawne, które w swej dyspozycji przewidują możność żądania, aby sąd ukształtował orzeczeniem określone stosunki prawne ${ }^{21}$. Powództwo o ukształtowanie prawa lub stosunku prawnego ma służyć realizacji istniejącej możliwości ukształtowania, którą przewidują normy prawa materialnego. Oznacza to, że mają one

\footnotetext{
${ }^{18}$ W. Siedlecki, Orzeczenia konstytutywne w postępowaniu cywilnym, [w:] Księga pamiątkowa ku czci Kamila Stefki, Warszawa, Wrocław 1967, s. 305-306.

${ }^{19}$ K. Korzan, op.cit., s. 106-107.

${ }^{20}$ Wyrok SN z 24.5.2012 r., sygn. akt V CSK 305/11, Legalis nr 544274.

${ }^{21}$ W. Siedlecki, Orzeczenia konstytutywne..., s. 311.
} 
prowadzić do bezpośredniego uzyskania formalnie prawomocnym wyrokiem konstytutywnym nowych stosunków prawnych, które nie istniały dotychczas ${ }^{22}$. Wyrok wydany w wyniku wytoczenia powództwa o ukształtowanie prawa lub stosunku prawnego może mieć różną treść - będzie on stwarzał nowy stosunek prawny, przekształcał istniejący już wcześniej albo uchyli istniejący stosunek prawny lub prawo ${ }^{23}$. Gdy chodzi o skutki orzeczenia konstytutywnego kształtującego prawo lub stosunek prawny, to mogą one być ukształtowane w czasie w rozmaity sposób. Stosownie do treści norm prawnych, które stanowią ich podstawę, skutki te mogą wystąpić ex nunc (na przyszłość, np. wyrok rozwodowy) lub ex tunc (z mocą wsteczną, np. wyrok o unieważnienie małżeństwa $)^{24}$.

Według kryterium zakresu prawa powództwa o ukształtowanie prawa lub stosunku prawnego można podzielić na powództwa z zakresu: prawa osobowego (np. o wyłączenie wspólnika spółki jawnej lub komandytowej), z zakresu prawa rzeczowego (np. o zniesienie służebności gruntowej za wynagrodzeniem i bez wynagrodzenia), z zakresu prawa zobowiązań (np. o naprawienie szkody lub przywrócenie do pierwotnego stanu), z zakresu prawa spadkowego (np. o niegodność dziedziczenia), z zakresu prawa handlowego (np. o rozwiązanie spółki na żądanie wspólnika z ważnych powodów), z zakresu prawa autorskiego (np. o uznanie wygaśnięcia praw autorskich).

Najistotniejsze z punktu widzenia omawianego zagadnienia związania sądów karnych orzeczeniami sądów cywilnych w sprawach o przestępstwo uchylania się od alimentacji są powództwa z zakresu prawa rodzinnego, do których należą: powództwo o rozwód, o unieważnienie małżeństwa, o ustalenie ojcostwa i roszczenia z tym związane, o zaprzeczenie małżeństwa, czy też o zniesienie wspólności małżeńskiej ${ }^{25}$.

Orzeczenia deklaratoryjne wydawane są przez sąd w toku postępowania, które toczy się na podstawie wytoczonego powództwa o świadczenie albo powództwa o ustalenie prawa lub stosunku prawnego. Istotą orzeczenia deklaratoryjnego jest to, że nie prowadzi ono do żadnej zmiany istniejącego stanu prawnego. Deklaruje ono jedynie, czy też ustala stosunek prawny albo obowiązek prawny świadczenia, który był wcześniej przedmiotem badania sądu w związku z wytoczonym powództwem lub zgłoszonym wnioskiem. Orzeczenia deklaratywne dotyczą więc skutku prawnego, który zaszedł już poza samym postępowaniem cywilnym i niezależnie od niego, natomiast ochrona prawna wyraża się w funkcji potwierdzenia tego,

\footnotetext{
${ }^{22}$ P. Osowy, Powództwa o uksztaltowanie stosunku prawnego, Warszawa 2015, s. 159.

${ }^{23}$ K. Piasecki, Wyrok pierwszej instancji..., s. 146.

${ }^{24}$ Ibidem, s. 147.

${ }^{25}$ P. Osowy, Powództwa o ukształtowanie..., s. 162-163.
} 
co jest albo nie jest, a nie stanu, który powinien istnieć ${ }^{26}$. Jeśli więc orzeczenie sądu cywilnego nie będzie prowadziło do żadnej zmiany w dotychczasowym stanie prawnym, a jedynie stwierdzi istnienie owego stanu, a sam skutek powstał już poza postępowaniem cywilnym, wówczas będziemy mieli do czynienia z orzeczeniem deklaratoryjnym ${ }^{27}$.

Jeżeli chodzi o pierwszy rodzaj wyroków - zasądzających świadczenie - należy na początku poczynić uwagę, że jest to jedna z najstarszych historycznie kategorii wyroków cywilnych. Zasądzenie polegca będzie na stwierdzeniu i nakazaniu określonego zachowania się, a w szczególności świadczenia, zaniechania lub znoszenia czegoś28. Obowiązek pozwanego będzie musiał wynikać ze stosunku cywilnoprawnego ${ }^{29}$. Powództwo o świadczenie skierowane jest na osiągnięcie określonego zachowania dłużnika. Powództwo to nie musi spełniać żadnych szczególnych przesłanek. W szczególności nie trzeba wykazać tutaj interesu prawnego (stanowi on jeden z wymogów powództwa o ustalenie istnienia lub nieistnienia stosunku prawnego lub prawa). Powództwo o świadczenie może być uwzględnione wyłącznie, gdy roszczenie będzie już wymagalne, a ponadto zaskarżalne i nieprzedawnione ${ }^{30}$. Jeżeli chodzi o wymagalność danego roszczenia, to należy wskazać, że pojęcie to łączy się z określeniem ram czasowych zobowiązania i ma znaczenie w zakresie formułowania ocen, które dotyczą przedawnienia tych roszczeń. Trzeba jednak zwrócić uwagę na fakt, że roszczenie będzie istniało bez względu na to, czy już jest wymagalne, czy jeszcze nie (wynika to m.in. z dyspozycji art. $120 \S 1$ k.c. ${ }^{31}$, który opiera się na ustaleniu dnia, w którym już istniejące roszczenie staje się wymagalne) ${ }^{32}$. Zgodnie z przepisami k.p.c. powództwo o świadczenie, które zostanie wytoczone przed dniem wymaganego terminu, powinno być oddalone, chyba że termin ten nastąpi najpóźniej w chwili zamknięcia rozprawy (stanowi o tym art. 316 k.p.c., zgodnie z którym zasądzeniu świadczenia nie stoi na przeszkodzie okoliczność, że stało się ono wymagalne dopiero w toku rozprawy). Jeżeli chodzi o drugą z cech roszczenia, czyli jego zaskarżalność, to przyjąć należy, że w procesie cywilnym istnieje możliwość skutecznego dochodzenia tylko takich roszczeń, których dochodzenie w sądzie nie będzie skazane z góry na niepowodzenie. Owa zaskarżalność roszczenia nie jest jednak pojęciem prawnym, w samym k.c. mowa jest jedynie o możliwości dochodzenia przed sądem lub innym organem państwowym wierzytelności. Taka formuła wydaje się być jednak niewystarczająca, bowiem

\footnotetext{
${ }^{26}$ P. Osowy, Powództwo o świadczenie, Warszawa 2006, s. 131.

${ }^{27}$ Z. Kwiatkowski, op.cit., s. 109.

${ }^{28}$ K. Piasecki, Wyrok pierwszej instancji..., s. 160-161.

${ }^{29}$ P. Osowy, Powództwo..., s. 91.

${ }^{30}$ K. Piasecki, Wyrok pierwszej instancji..., s. 161-162.

${ }^{31}$ Ustawa z 23.4.1964 r. - Kodeks cywilny, t.j.: Dz.U. z 2020 r., poz. 1740 ze zm.

${ }^{32}$ P. Osowy, Powództwo..., s. 97.
} 
każde roszczenie cywilnoprawne może być przedmiotem postępowania, natomiast jego wynik może być już różny. Powództwo może być wytoczone przez każdego, kto twierdzi, że przysługuje mu uprawnienie wynikające ze stosunku materialnoprawnego, natomiast to sąd w toku postępowania będzie miał za zadanie ustalić, czy dane twierdzenia, stanowiące podstawę żądania powoda, rzeczywiście znalazły swe uzasadnienie w przepisach prawa materialnego ${ }^{33}$.

Drugim powództwem, w wyniku którego sąd w postępowaniu cywilnym wyda wyrok deklaratoryjny, jest powództwo o ustalenie istnienia lub nieistnienia prawa lub stosunku prawnego. Pomimo faktu, iż koncepcja wyroku ustalającego jest znana już od dawna, to wyrok ustalający wykształcił się jednak jako chronologicznie późniejszy niż zasądzający świadczenie ${ }^{34}$. Powództwo to zostało uregulowane w art. 189 k.p.c., zgodnie z którym powód może żądać ustalenia przez sąd istnienia lub też nieistnienia prawa lub stosunku prawnego wtedy, gdy ma w tym interes prawny. Ustalenie w przypadku tego powództwa polega jedynie na deklarowaniu z mocą wiążącą istnienia lub nieistnienia stosunku prawnego niepewnego lub spornego $^{35}$. Jak zostało już wskazane, wyroki zapadłe w sprawach wszczętych na podstawie art. 189 k.p.c. mają charakter deklaratoryjny i jako środek ochrony stosunków cywilnoprawnych mają służyć usunięciu sporu lub też stanu niepewności co do prawa lub stosunku prawnego. Żądanie to będzie mogło odnieść skutek wyłącznie w określonych sytuacjach, a znajduje to wyraz w podstawie powództwa o ustalenie, którą stanowi przesłanka interesu prawnego. Pojęcie interesu prawnego powinno być traktowane jako szczególny rodzaj klauzuli stanowiącej element konstrukcji powództwa wniesionego na podstawie art. 189 k.p.c. Ponadto należy je interpretować zgodnie z uwzględnieniem szeroko pojmowanego dostępu do sądu w celu zapewnienia ochrony prawnej postaci ustalenia stosunku prawnego lub prawa $\mathrm{W}$ sensie pozytywnym lub negatywnym. Interes prawny można również zdefiniować jako obiektywną potrzebę uzyskania określonej treści wyroku ${ }^{36}$. Dlatego też interes prawny nie wystąpi w żądaniu ustalenia istnienia lub nieistnienia stosunku prawnego lub prawa osoby, która może osiągnąć w pełni ochronę swoich praw inną drogą ${ }^{37}$. Na koniec rozważań dotyczących pojęcia interesu prawnego wskazać należy, że interes ten stanowi przesłankę merytoryczną powództwa o ustalenie, tak więc jego brak będzie powodował oddalenie powództwa. Jest to kategoria obiektywna, dlatego interes prawny musi być wykazany przez

\footnotetext{
${ }^{33}$ P. Pogonowski, Realizacja prawa do sadu w postepowaniu cywilnym, Warszawa 2005, s. 21.

${ }^{34}$ K. Piasecki, Wyrok pierwszej instancji..., s. 147.

${ }^{35}$ Ibidem, s. 147-148.

${ }^{36}$ W. Borysiak (red.), Postępowanie cywilne. Orzecznictwo, Warszawa 2008, s. 224-225.

${ }^{37}$ Wyrok s.apel. w Katowicach z 1.12.2016 r., sygn. akt I ACa 767/16, Legalis nr 1558617.
} 
powoda $^{38}$. Gdy chodzi o kwestię przedmiotu powództwa, trzeba zwrócić uwagę na fakt, że na podstawie art. 189 k.p.c. można domagać się ustalenia wyłącznie prawa lub stosunku prawnego, a nie faktów. Na koniec trzeba również wskazać, że powództwo o ustalenie istnienia lub nieistnienia prawa lub stosunku prawnego ma charakter prewencyjny. Ten charakter wynika $\mathrm{z}$ istoty interesu prawnego $\mathrm{w}$ żądaniu samodzielnego ustalenia prawa lub też stosunku prawnego. Interes ten natomiast odpadnie w sytuacji, gdy prawo powoda już zostało naruszone i zaistniała możliwość dochodzenia świadczenia wynikającego z naruszenia. Samo wytoczenie powództwa o ustalenie nie stoi na przeszkodzie, by jednocześnie wytoczyć powództwo o świadczenie, w przypadku gdy np. ze zdarzenia powodującego szkodę przysługują już poszkodowanemu określone świadczenia, natomiast z tego zdarzenia mogą w przyszłości powstać inne szkody, których w danej chwili nie można dochodzić39.

\section{Przestępstwo uchylania się od alimentacji w polskim porządku prawnym}

Społeczeństwo prawidłowo egzystujące jest ściśle powiązane $\mathrm{z}$ właściwym funkcjonowaniem rodzin, które najczęściej stanowią jego podstawowe komórki. Rodzina stanowi fundament dla wychowania dzieci, a także stwarza najlepsze warunki do życiowego funkcjonowania ludzi w szerszych kręgach społeczeństwa ${ }^{40}$. Przestępczość przeciwko rodzinie, opiece i młodzieży stanowi ważki problem społeczny, dlatego też kwestia związania sądów karnych orzeczeniami sądów cywilnych w sprawach o przestępstwa uchylania się od alimentacji jest istotna. Już pod koniec lat 80. ubiegłego wieku podjęte zostały działania w celu przeprowadzenia badania zagadnienia przestępczości przeciwko rodzinie, opiece i młodzieży ze szczególnym uwzględnieniem przestępstw niealimentacji (uregulowanych w ówczesnym art. 186 k.k. $\left.{ }^{41}\right)^{42}$.

Według raportu Biura Informacji Gospodarczej dotyczącego dłużników alimentacyjnych w Polsce na koniec września 2016 r. długi alimentacyjne opiewały na kwotę 9,4 mld $\mathrm{z}^{43}$. Liczba dłużników wpisanych do Biura Informacji Gospodarczej wyniosła natomiast 282 300. Dwóch na pięciu statystycznych dłużników alimentacyjnych posiada

\footnotetext{
${ }^{38}$ A. Zieliński, [w:] Kodeks postępowania cywilnego. Komentarz, A. Zieliński, K. Flaga-Gieruszyńska (red.), Warszawa 2017, s. 392.

${ }^{39}$ Ibidem.

${ }^{40}$ H. Kołakowska-Przełomiec, Przestępstwa niealimentacji, Wrocław 1989, s. 7.

${ }^{41}$ Ustawa z 19.4.1969 r. - Kodeks karny, Dz.U. nr 13, poz. 94 ze zm.

${ }^{42}$ H. Kołakowska-Przełomiec, Przestępstwa niealimentacji..., s. 10.

43 Raport - dtużnik alimentacyjny, BIG InfoMonitor 3/2016, https://www.big.pl/download/alimenty/raport_dluznik_alimentacyjny_pazdziernik_2016.pdf, [dostęp: 4.4.2021].
} 
ponadto inne niezapłacone jeszcze zobowiązania, co powoduje trudności w wyegzekwowaniu niespłaconych długów alimentacyjnych ${ }^{44}$. W przedziale czasowym od 30.6.2016 r. do 30.9.2016 r. liczba dłużników alimentacyjnych wzrosła o 3479 osoby. Wśród tej kategorii dłużników dominują mężczyźni, stanowią bowiem ponad 95 \% osób, które wpisane zostały do bazy Biura Informacji Gospodarczej. Jeśli chodzi o wartość samego zobowiązania z tytułu niezapłaconych alimentów, to średnia jego wartość na jednego dłużnika alimentacyjnego systematycznie rośnie ${ }^{45}$. Od 30.6.2016 r. do 30.9.2016 r. wzrosła o 859 zł i opiewała na kwotę 33160 zł. Najwyższa kwota z tytułu niezapłaconych alimentów wyniosła ok. 454000 zł ${ }^{46}$. Jak wynika z powyżej przywołanych danych statystycznych, problem dłużników alimentacyjnych w Polsce jest cały czas obecny, a ich liczba stale rośnie. Egzekwowanie owych zobowiązań jest natomiast trudnym zadaniem, ponieważ ponad 100000 osób posiada, obok zadłużenia alimentacyjnego, także innego rodzaju świadczenia, które muszą spełnić ${ }^{47}$.

\section{Zmienione przepisy k.k. wymierzone $w$ niepłacących na dzieci spowodowały $w$} latach 2017 i 2018 wzrost liczby dłużników alimentacyjnych. W ciągu pierwszego półrocza 2018 r. w Biurze Informacji Gospodarczej przybyło ich do 319 tysięcy, a kwota zaległości wzrosła do $11,9 \mathrm{mld} \mathrm{z}^{48}$.

Jak wynika z policyjnych statystyk, w I półroczu 2018 r. wszczętych zostało ponad 90 000. spraw przeciw dłużnikom alimentacyjnym, podczas gdy w analogicznym okresie zeszłego roku, czyli jeszcze przed zmianą prawa, było to jedynie $10000 .{ }^{49}$.

Obowiązek alimentacyjny służy określeniu stosunku prawnego powstałego w wyniku zaistnienia zdarzeń, z którymi ustawa wiąże powstanie obowiązku alimentacyjnego. Jako przykład takich zdarzeń wskazać można urodzenie dziecka, przysposobienie dziecka, czy zawarcie małżeństwa ${ }^{50}$. Zgodnie z treścią art. 133 k.r.o. ${ }^{51}$ rodzice są obowiązani do świadczeń alimentacyjnych względem dziecka, które nie jest w stanie samodzielnie się utrzymać, chyba że dochody z majątku dziecka wystarczają na pokrycie kosztów jego utrzymania i wychowania. Rodzicielski obowiązek utrzymywania niesamodzielnych dzieci nie został skonkretyzowany podmiotowo (granice wieku dziecka uprawnionego nie są określone w przepisie) ani też przedmiotowo (niesamodzielność dziecka nie jest doprecyzowana w ustawie). W odróżnieniu

\footnotetext{
${ }^{44}$ Ibidem.

${ }^{45}$ Ibidem.

${ }^{46}$ Ibidem.

${ }^{47}$ Ibidem.

${ }^{48}$ https://media.bik.pl/publikacje/read/397423/raport-dluznik-alimentacyjny-lipiec-2018, [dostęp: 4.4.2021].

${ }^{49}$ Ibidem.

${ }^{50}$ M. Szewczyk, [w:] System prawa karnego, t. 10. Przestepstwa przeciwko dobrom indywidualnym, J. Warylewski (red.), Warszawa 2012, s. 956.

${ }^{51}$ Ustawa z 25.2.1964 r. - Kodeks rodzinny i opiekuńczy, t.j.: Dz.U. z 2020 r., poz. 1359.
} 
więc od ogólnej przesłanki obowiązku alimentacyjnego, którą jest niedostatek uprawnionego (wynika to $\mathrm{z}$ treści art. $133 \S 2$ k.r.o.), przesłanką obowiązku alimentacyjnego rodziców względem dziecka, które nie jest jeszcze w stanie utrzymać się samodzielnie, jest zasadniczo sama niezdolność dziecka do samodzielnego utrzymania się, a więc również wtedy, gdy znajduje się ono w niedostatku. Konsekwencją jest obowiązek rodziców dostarczania dziecku środków utrzymania i wychowania istnieje od chwili jego urodzenia ${ }^{52}$. Brak samodzielności należy odnieść zarówno do małoletniego, który pozostaje pod władzą rodzicielską, jak również do dzieci pełnoletnich, które nie potrafią (bez własnej winy) utrzymać się bez pomocy rodziców ze względu na sytuację życiową. W szczególności chodzi tu o chorobę, brak zawodu, wykształcenia albo niemożność znalezienia pracy ${ }^{53}$. Przy orzeczeniu o obowiązku alimentacyjnym rodziców wobec dziecka, które osiągnęło już pełnoletność, pod uwagę należy wziąć fakt, czy wykazuje ono chęć dalszej nauki, a także, czy jego osobiste zdolności i cechy charakteru umożliwiają rzeczywiste kontynuowanie przez nie nauki ${ }^{54}$. Ponadto, trzeba mieć na względzie, iż osiągnięcie przez dziecko pełnoletności, jak również uzyskanie przez nie środków finansowych z tytułu pracy zawodowej, renty inwalidzkiej albo zasiłku dla bezrobotnych, nie będzie automatycznie skutkowało ustaniem obowiązku alimentacyjnego ciążącego na rodzicach ${ }^{55}$.

Należy zwrócić uwagę na fakt, iż zwolnienia z obowiązku alimentacyjnego (wszelkiego rodzaju) lub też świadczeń z nim związanych mają charakter wyjątkowy. Zgodnie z ogólnymi regułami interpretacyjnymi powinny być one rozumiane w sposób ścisły (a nie rozszerzający). Dlatego też ewentualne umorzenie winno mieć miejsce jedynie, gdy sytuacja dochodowa zobowiązanego lub też jego rodziny nie pozwala mu na wywiązywanie się z ciążącego na nim obowiązku alimentacyjnego. Taki stan powinien być efektem czynników obiektywnych, na które nie ma wpływu zobowiązany, ponieważ tylko takie przesłanki mogą stanowić uzasadnienie umorzenia jakichkolwiek należności z tytułu świadczeń wypłacanych z funduszu alimentacyjnego ${ }^{56}$.

Uchylanie się od obowiązku alimentacji penalizował już kodeks karny z 1932 r. ${ }^{57}$. Artykuł 201 ówcześnie obowiązującego kodeksu stanowił „kto przez złośliwe uchylanie się od ciążącego na nim z mocy ustawy obowiązku łożenia na utrzymanie osoby najbliższej

\footnotetext{
${ }^{52}$ K. Pietrzykowski, [w:] Kodeks rodzinny i opiekuńczy. Komentarz, K. Pietrzykowski (red.), Legalis 2020.

${ }^{53}$ K. Gromek, Kodeks rodzinny i opiekuńczy, Warszawa 2016, s. 280.

${ }^{54}$ Wyrok SN z 30.6.1999 r., sygn. akt III CKN 199/99, Legalis nr 53763.

${ }^{55}$ Wyrok SN z 14.5.2002 r., sygn. akt V CKN 1032/00, Legalis nr 291951.

${ }^{56}$ Wyrok WSA w Łodzi z 12.1.2011 r., sygn. akt II SA/Łd 1111/10, Legalis nr 387529.

${ }^{57}$ Rozporządzenie Prezydenta Rzeczypospolitej z 11.7.1932 r. - Kodeks karny, Dz.U. nr 60, poz. 571 ze zm.
} 
doprowadza tę osobę do nędzy lub do konieczności korzystania ze wsparcia, podlega karze więzienia do lat 3 lub karze aresztu do lat 3”. Ta sama kara przewidziana była wobec osób, jeśli obowiązek łożenia stwierdzony był prawomocnym lub podlegającym wykonaniu orzeczeniem sądu. Zwrot ,złośliwe uchylanie się” rozumiany był jako szczególny sposób nastawienia sprawcy owego czynu zabronionego ${ }^{58}$. Z kolei kodeks karny z 1969 r. przestępstwo niealimentacji ujmował $\mathrm{w}$ art. 186. Przepis ten stanowił, że „kto uporczywie uchyla się od wykonania ciążącego na nim na mocy ustawy obowiązku łożenia na utrzymanie dziecka, rodziców lub innej osoby najbliższej i przez to naraża ją na niemożność zaspokojenia podstawowych potrzeb życiowych, podlega karze pozbawienia wolności do lat 3". Znamię „uporczywości” zastąpiło wcześniejszą „złośliwość”59.

Artykuł 209 obecnie obowiązującego k.k. został znowelizowany w 2017 r. ${ }^{60}$ W związku z tym nastąpiło odejście od znamion w postaci „uporczywości” uchylania się od obowiązku alimentacyjnego oraz skutku w postaci „narażenia osoby uprawnionej na niemożność zaspokojenia podstawowych potrzeb życiowych". Projektodawca zrezygnował z penalizacji uchylania się od wszelkiego rodzaju świadczeń alimentacyjnych. Przestępstwo niealimentacji odnosi się obecnie do świadczeń określonych co do wysokości (tj. świadczeń pieniężnych), ponieważ $\mathrm{w}$ istocie tylko z taką formą niewykonywanych świadczeń alimentacyjnych mają do czynienia organy ścigania i sądy w postępowaniu karnym. Zgodnie z treścią art. $209 \S 1$ k.k. ${ }^{61}$ przestępstwo niealimentacji popełnia ten, „kto uchyla się od wykonania obowiązku alimentacyjnego określonego co do wysokości orzeczeniem sądowym, ugodą zawartą przed sądem albo inną umową, jeżeli łączna wysokość powstałych wskutek tego zaległości stanowi równowartość co najmniej 3 świadczeń okresowych albo jeżeli opóźnienie zaległego świadczenia innego niż okresowe wynosi co najmniej 3 miesiące". W tym przypadku jako najważniejsze należy wskazać akta stanu cywilnego oraz wyrok sądu cywilnego, w którym dochodzi do ustalenia ojcostwa lub macierzyństwa. Celem zmiany treści art. 209 k.k. (przed nowelizacją przepis ten stanowił, że karze podlegał ten, kto uporczywie uchylał się od wykonywania ciążącego na nim z mocy ustawy lub orzeczenia sądowego obowiązku opieki przez nałożenie na utrzymanie osoby najbliższej lub innej osoby i wskutek tego narażał ją na niemożność zaspokojenia podstawowych potrzeb życiowych) było wzmocnienie realizacji obowiązku opieki poprzez zaspokajanie potrzeb materialnych osób niebędących w stanie

\footnotetext{
${ }^{58}$ M. Szewczyk, op.cit., s. 954.

${ }^{59}$ A. Tobis, Główne przestępstwa przeciwko rodzinie, Poznań 1980, s. 56.

${ }^{60}$ Ustawa z 23.3.2017 r. o zmianie ustawy - Kodeks karny oraz ustawy o pomocy osobom uprawnionym do alimentów, Dz.U. poz. 952.

${ }^{61}$ Ustawa z 6.6.1997 r. - Kodeks karny, t.j.: Dz.U. z 2020 r., poz. 1444.
} 
spełnić ich samodzielnie. W uzasadnieniu projektu nowelizacji wskazano, iż obowiązkiem państwa jest podnoszenie poziomu życia społeczeństwa. Konsekwencją takich działań jest stała poprawa warunków materialnych obywateli. W związku z tym koniecznym było także szersze zapewnienie realizacji ochrony uprawnień alimentacyjnych, które przysługują osobom uprawnionym $^{62}$. W nowym ujęciu w art. 209 k.k. stypizowano w $\S 1$ przestępstwo formalne, brzmieniu dotychczasowego typu podstawowego (dawny $\S 1$ ) nadano natomiast z pewnymi modyfikacjami charakter typu kwalifikowanego (obecny $\S 1$ 1a). Jednocześnie $w \quad \S 1$ zrezygnowano ze znamienia uporczywości, wskazując jednak, że wysokość zaległości stanowić ma równowartość co najmniej trzech świadczeń okresowych albo opóźnienie zaległego świadczenia innego niż okresowe wynosi co najmniej trzy miesiące ${ }^{63}$. W $\S 1$ ustawodawca wprowadził więc całkowicie nowy typ czynu zabronionego, zagrożony niższą karą (grzywna, ograniczenie wolności lub pozbawienie wolności do roku), jednak obejmujący zachowania, które dotychczas nie wyczerpywały znamion przestępstwa. W konsekwencji doszło do rozszerzenia zakresu kryminalizacji czynu z art. 209 k.k. na zachowania, które nie niosą za sobą jeszcze zagrożenia dla zapewnienia uprawnionemu zaspokojenia jego podstawowych potrzeb ${ }^{64}$.

\section{Związanie sądów karnych orzeczeniami sądów cywilnych w sprawach o przestępstwo uchylania się od alimentacji}

Sąd karny w przypadku przestępstwa niealimentacji związany będzie wyrokiem sądu cywilnego, w którym dochodzi do ustalenia ojcostwa lub macierzyństwa. Jest to przykład świadczenia o ukształtowanie stosunku prawnego lub prawa, a wyrok wydany w takiej sprawie będzie wyrokiem konstytutywnym. Sąd karny związany więc będzie rozstrzygnięciem, które zapadnie w przypadku wytoczenia przez prokuratora powództwa o ustalenie ojcostwa lub macierzyństwa. K. Korzan wskazywał, dlaczego powództwo o ustalenie ojcostwa i wyrok w nim wydany nie może być uznany za deklaratoryjny. Gdyby uznać, że wyrok ustalający ma mieć charakter deklaratywny, takie powództwo winno zmierzać do ustalenia

62 Rządowy projekt ustawy o zmianie ustawy - Kodeks karny z dnia 3.1.2017 r., druk nr 1193, https://orka.sejm.gov.pl/Druki8ka.nsf/0/88242DAE71B97187C12580A500613635/\%24File/1193.pdf, [dostęp: 4.4.2021].

${ }^{63}$ A. Duda, D. Sokołowska, Nowe granice kryminalizacji przestępstwa niealimentacji oraz mechanizmy redukcji karania wedtug znowelizowanego brzemienia art. 209 k.k., CPKiNP 2017, z. 4, s. 28.

${ }^{64}$ M. Borodziuk, Zakres kryminalizacji przestęstwa niealimentacji po nowelizacji w 2017 r., Prok. i Pr. 2018, nr 4, s. 44-45. 
już istniejącego stosunku prawnego lub prawa ${ }^{65}$. Należy jednak zwrócić uwagę na fakt, że taki stosunek nie istnieje między dzieckiem pozamałżeńskim a biologicznym ojcem. Urodzenie będzie bowiem tworzyło stosunek prawny jedynie w odniesieniu do męża matki dziecka, ze względu na istniejące domniemanie pochodzenia $\mathrm{z}$ małżeństwa ${ }^{66}$. K. Korzan wskazał, iż wyrok tworzący nowy stan prawny w zakresie przez niego oznaczonym, sąd karny obowiązany jest przyjąć i uznać owy stan za konkretną rzeczywistośćc7 ${ }^{67}$ W związku z tym sąd karny nie będzie mógł nie uznać mężczyzny określonego w sentencji wyroku sądu cywilnego za ojca dziecka pozamałżeńskiego ${ }^{68}$. Zupełnie inaczej przestawiałaby się sytuacja, gdyby wyrok ustalający ojcostwo uznać jednak za deklaratoryjny. W takim przypadku sąd karny nie byłby związany tym orzeczeniem sądu cywilnego. Mógłby więc ustalić zupełnie inaczej przesłanki w sprawie karnej o przestępstwo uchylania się od alimentacji i uznać, że ojcem dziecka jest zupełnie inna osoba niż ta, którą sąd ustalił w postępowaniu cywilnym. Doprowadziłoby to więc do sytuacji, w której ustalenia sądu karnego podważałyby stan cywilny pozamałżeńskiego dziecka $\mathrm{w}$ opinii publicznej ${ }^{69}$. Analogicznie sytuacja wygląda w przypadku wyroków ustalających macierzyństwo. W tej sytuacji sąd w postępowaniu cywilnym również tworzy nowy stan prawny. Z chwilą uprawomocnienia się danego wyroku powstanie więc między kobietą a dzieckiem stosunek pokrewieństwa oraz wynikające z niego roszczenia alimentacyjne, czy spadkowe.

Jeśli chodzi o akta stanu cywilnego, to problem istniał podczas obowiązywania dekretu z 8.6.1955 r. - Prawo o aktach stanu cywilnego ${ }^{70}$. Ówczesny art. 25 dekretu zawierał regulację, według której akta stanu cywilnego stanowiły wyłączny dowód zdarzeń w nich stwierdzonych, a ich niezgodność $\mathrm{z}$ prawdą mogła być udowodniona $\mathrm{w}$ postępowaniu nieprocesowym o unieważnienie lub sprostowanie aktu. Istniały wtedy wątpliwości, czy można dopuścić dowód w procesie karnym, który zmierzał do obalenia prawdziwości wynikających z tego właśnie $\mathrm{aktu}^{71}$. Zdaniem A. Woltera oraz J. Litwina zasada swobodnej oceny dowodów obecna w kodeksie postępowania karnego oraz brak ograniczeń co do dopuszczalności dowodów przemawiają za tym, by prawa stanu mogły być dowodzone na równi z innymi okolicznościami, w dodatku każdym możliwym środkiem dowodowym ${ }^{72}$. Ustawa - Prawo o aktach stanu

\footnotetext{
${ }^{65}$ K. Korzan, op.cit., s. 187.

${ }^{66}$ Z. Ziembiński, O metodzie analizowania ,stosunku prawnego”, PiP 1967, nr 2, s. 197.

${ }^{67}$ K. Korzan, op.cit., s. 187.

${ }^{68}$ Ibidem.

${ }^{69}$ Ibidem.

${ }^{70}$ Dz.U. nr 25, poz. 151.

${ }^{71}$ T. Gardocka, Prejudycjalność polskim procesie karnym, Warszawa 1987s. 71-72.

${ }^{72}$ Tak np. A. Wolter, Z zagadnień polityki legislacyjnej. Na marginesie Prawa o aktach stanu cywilnego, NP 1956, nr 6, s. 95; J. Litwin, Prawo o aktach stanu cywilnego. Komentarz, Warszawa 1961, s. 232.
} 
cywilnego z $1986 \mathrm{r}^{73}$ oraz obecnie obowiązująca ustawa o aktach stanu cywilnego z $2014 \mathrm{r} .{ }^{74}$ również zawierają taką regulację.

Można więc postawić w tym miejscu pytanie, czy skoro teraz nie występuje przepis wprost stanowiący o wyłączności dowodu zdarzeń stwierdzonych w aktach stanu cywilnego, to sąd karny jest w ogóle związany tymi aktami? Należy stwierdzić, iż akta stanu cywilnego mają jednak moc wiążącą nie tylko w postępowaniu cywilnym albo administracyjnym, ale także w postępowaniu karnym. Inne założenie doprowadziłoby do sytuacji, gdy określona osoba $\mathrm{w}$ postępowaniu cywilnym albo administracyjnym zostałaby uznana za dziecko mężczyzny wskazanego w danym akcie urodzenia (ze wszystkimi tego konsekwencjami), natomiast w postępowaniu karnym taka osoba mogłaby być uznana za dziecko zupełnie innego mężczyzny. Taka sytuacja nie może być zaakceptowana, bowiem doprowadziłoby to do chaosu prawnego $^{75}$. Podobnie wypowiedział się Sąd Apelacyjny w Lublinie w jednym z wyroków ${ }^{76}$. Podkreślił, że akty stanu cywilnego stanowią wyłączny dowód zdarzeń w nim stwierdzonych, a ich niezgodność z prawdą może być udowodniona jedynie w postępowaniu sądowym. Sąd Najwyższy w wyroku z 1998 r. ${ }^{77}$ także wskazał, że odstępstwa od zasady samodzielności jurysdykcyjnej sądu karnego nie mogą być ograniczone wyłącznie do przypadku wskazanego w art. $4 \S 2$ k.p.k. (a obecnie art. $8 \S 2$ k.p.k.). Mogą bowiem wynikać również z innych postanowień ustawy, przy czym dotyczy to nie tylko kodeksu postępowania karnego, ale także innych aktów normatywnych o randze ustawy.

$\mathrm{Na}$ podstawie przytoczonych orzeczeń oraz poglądów doktryny należy stanąć na stanowisku, że w przypadku przestępstwa uchylania się od alimentacji sąd karny będzie związany w postępowaniu aktami stanu cywilnego, w szczególności aktem urodzenia dziecka, w którym wskazani są rodzice. Tak jak zostało już wskazane, odmienne stanowisko prowadziłoby do sytuacji, w których akty stanu cywilnego byłyby respektowane w postępowaniu cywilnym, nie zaś w postępowaniu karnym. Ustawodawca dlatego przewidział odstępstwa od zasady samodzielności jurysdykcyjnej sądu karnego, aby nie doprowadzić do chaosu prawnego i poszanowania wzajemnych relacji między zachodzącymi między postępowaniami karnymi i cywilnymi.

\footnotetext{
73 T.j.: Dz.U. z 2011 r., nr 212, poz. 1264.

74 T.j.: Dz.U. z 2020 r., poz. 463.

75 A. Sakowicz, [w:] Kodeks postępowania karnego. Komentarz, A. Sakowicz (red.), Warszawa 2016, s. 55.

${ }^{76}$ Wyrok s.apel. w Lublinie z 21.2.2008 r., sygn. akt II AKa 6/08, Legalis nr 112210; wyrok dotyczył poprzednio obowiązującej ustawy Prawo o aktach stanu cywilnego, jednak zapis poprzednio obowiązującego art. 4 owej ustawy został powtórzony w obecnym art. 3.

${ }^{77}$ Wyrok SN z 1.12.1998 r., sygn. akt IV KKN 492/97, Legalis nr 43115.
} 


\section{Podsumowanie}

Orzeczeniami kształtującymi prawo lub stosunek prawny, a więc konstytutywnymi, będą wyłącznie takie, które wydane zostały w wyniku wytoczenia powództwa o ukształtowanie prawa lub stosunku prawnego. Tylko ten rodzaj powództwa (obok istniejących powództw o zasądzenie świadczenia oraz o ustalenie istnienia lub nieistnienia prawa lub stosunku prawnego) powoduje skutki w postaci bezpośredniego uzyskania prawomocnym wyrokiem konstytutywnym nowych stosunków prawnych, które dotychczas nie istniały. Wyrok wydany W wyniku wytoczenia powództwa o ukształtowanie prawa lub stosunku prawnego może mieć różną treść - będzie on stwarzał nowy stosunek prawny, przekształcał istniejący już wcześniej albo uchyli istniejący stosunek prawny lub prawo, jednak zawsze doprowadzi do wykształcenia nowej sytuacji.

W praktyce orzeczenia konstytutywne mogą być wydawane w sprawach dotyczących różnych aspektów, począwszy od spraw z zakresu prawa osobowego, prawa rzeczowego, czy prawa zobowiązań, a skończywszy na wytoczeniu powództwa z zakresu prawa rodzinnego. Przy tej ostatniej kategorii istotny jest wpływ orzeczeń sądów cywilnych, w których dochodzi do ustalenia ojcostwa lub macierzyństwa na późniejsze ustalenia sądu karnego przy orzekaniu w przedmiocie przestępstwa uchylania się od alimentacji. Dane statystyczne ukazane w opracowaniu wskazują na istniejący cały czas problem obecności dłużników alimentacyjnych uchylających się od spełnienia ciążącego na nich obowiązku alimentacyjnego. Istotne więc było przeanalizowanie instytucji związania sądów karnych orzeczeniami sądów cywilnych w sprawach o przestępstwo niealimentacji. W przypadku tych spraw sądy karne związane są wyrokami sądów cywilnych, w którym dochodzi do ustalenia ojcostwa lub macierzyństwa, a także aktami stanu cywilnego.

\section{Summary \\ Binding of criminal courts with final decisions of civil courts on the example of cases concerning the offenses of maintenance evasion \\ Despite the existence of the principle of judicial independence in Polish criminal proceedings, according to which the criminal court independently decides factual and legal issues, and is not bound by a decision of another court or authority, the legislator provided}


for exceptions. The court in criminal proceedings is bound by legally valid court decisions that shape the law or legal relationship. Therefore, despite the differences existing between criminal proceedings and civil proceedings, the fact that judgments issued in the course of civil proceedings affect the pending criminal proceedings should not remain indifferent. Such a decision will have an impact on the shape of these proceedings and the decisions taken by the criminal court. An example is the decisions of civil courts which have an impact on the judgments of criminal courts issued in relation to the offense of maintenance evasion. On their example, it will be shown to what extent the court is limited in its independence when deciding in criminal proceedings.

\section{Renata Badowiec}

Magister prawa; w 2017 r. ukończyła studia prawnicze na Wydziale Prawa i Administracji UMK w Toruniu; uczestnik studiów doktoranckich na Wydziale Prawa i Administracji UMK; główne obszary zainteresowań: uprawnienia pokrzywdzonego w postępowaniu karnym, dochodzenie roszczeń cywilnoprawnych w postępowaniu karnym, rzetelny proces karny, udział zakładu ubezpieczeń w postępowaniu karnym. 